\title{
Against Individualistic Justifications of Property Rights
}

\author{
ROWAN CRUFT \\ University of Stirling
}

In this article I argue that, despite the views of such theorists as Locke, Hart and Raz, most of a person's property rights cannot be individualistically justified. Instead most property rights, if justified at all, must be justified on non-individualistic (e.g. consequentialist) grounds. This, I suggest, implies that most property rights cannot be morally fundamental 'human rights'.

\section{INDIVIDUALISTIC JUSTIFICATION}

What, if anything, justifies the existence of property rights? In my view, property rights are justified because they serve the collective interest. Against this, many theorists regard the justification of property rights as individualistic. I show in this article that most property rights cannot be individualistically justified. Furthermore, I argue that individualistic justification is the hallmark of those especially morally important rights that we call 'human rights'. Hence because most property rights cannot be individualistically justified, most property rights cannot be human rights.

My concept, 'individualistic justification', refers to an approach to rights adopted by a range of thinkers including Locke, Hart and Raz, an approach that contrasts with consequentialist, communitarian and contractualist accounts of the justification of rights. A person P's right $R$ is individualistically justified if and only if:

1. Some genuine feature $\mathrm{F}$ of $\mathrm{P}$ is of sufficient intrinsic importance on its own to constitute a powerful pro tanto reason in favour of P's holding a right that will protect, serve or in some other way ensure respect for $\mathrm{F}-$ and $\mathrm{R}$ is such a right.

2. This pro tanto reason is undefeated and hence $R$ is justified.

Three terms in the definition merit explanation. (a) Genuine. A right is only individualistically justified if it is justified on the basis of some genuine feature of its holder such as P's interest in bodily integrity, rather than some gimmicky relational feature such as P's-being-such-that-P's-holding-R-would-serve-the-collectiveinterest. To rule out justifications of the latter type, one should read 'genuine feature' as referring to features of $\mathrm{P}$ whose existence is logically (but not necessarily causally) independent of the existence of P's wider community, and of the collective interest. (b) Intrinsic. 
Some genuine feature of P, such as P's life or P's liberty, might be of instrumental importance in securing protection for some feature of someone else - for example, a pregnant woman's life is of great importance in securing the life of her unborn child. ${ }^{1} \mathrm{~A}$ pregnant woman's right not to be executed, justified only on the basis of the instrumental importance of her life for her unborn child, would not qualify as individualistically justified on my account. Rights are only individualistically justified when they are justified by the intrinsic rather than instrumental value of some genuine feature of the rightholder. $^{2}$ (c) Powerful. Consequentialists (and also some communitarians and contractualists) will not deny the individualistic claim that certain genuine features (perhaps P's interests or preferences) of a person $\mathrm{P}$ are of sufficient intrinsic importance on their own to constitute pro tanto reasons in favour of rights for $\mathrm{P}$. But consequentialists, communitarians and contractualists will deny that these pro tanto reasons are 'powerful' in the following sense: powerful pro tanto reasons cannot be defeated by most competing reasons; powerful pro tanto reasons are normative 'breakwaters' that can rarely be defeated. In particular, such reasons cannot be defeated merely by the collective interest, or by some group's interest, or by the choices of a majority of contractors. ${ }^{3}$ Thus individualistic justifications of rights, as I understand them, contrast with consequentialist, communitarian and contractualist justifications.

The intuitive idea is that an individualistically justified right is justified ultimately by the great intrinsic importance of certain features of its holder, considered independently of their effect on other people.

1 This example is drawn from Joseph Raz, 'Rights and Individual Well-Being', in his Ethics in the Public Domain: Essays in the Morality of Law and Politics (Oxford, 1995), p. 50 .

${ }_{2}^{2}$ I use 'intrinsic value' here simply to mean non-instrumental value. Thus I follow Raz and diverge from Korsgaard, who uses 'intrinsic value' to refer only to a sub-class (the 'unconditionally valuable') of what is non-instrumentally valuable (Christine Korsgaard, 'Two Distinctions in Goodness', The Philosophical Review 92 (1983), pp. 169-95; for Raz's broader use of 'intrinsic value' see his The Morality of Freedom (Oxford, 1986), pp. 177-8).

${ }_{3}^{3}$ Why are the reasons that individualistically justify rights defeasible at all? In my view, there can be no right that would be justified even if it imposed massive burdens on others; hence all rights - including individualistically justified rights - must be justified on the basis of defeasible reasons. To say that these reasons are 'powerful' is to say that, just as rights themselves are 'trumps' or 'breakwaters' that normally defeat 'some background justification for political decisions that states a goal for the community as a whole', so the reasons in favour of individualistically justified rights are similarly 'trumps' or 'breakwaters' that normally defeat competing reasons (the quotation is from Ronald Dworkin, 'Rights as Trumps', Theories of Rights, ed. J. Waldron (Oxford, 1984), p. 153; for the idea of rights as 'breakwaters', see David Rodin, War and Self-Defense (Oxford, 2002), p. 25). By contrast, consequentialist, communitarian and contractualist approaches to rights, while recognizing that rights themselves are normative 'trumps' or 'breakwaters', deny that rights' justification is grounded in 'trumping' or 'breakwater' reasons that cannot be defeated by the collective interest or by some group's interest, or by the choices of a majority of contractors. 
These features constitute powerful reasons in favour of rights for the feature-bearers. For example, Fred's right not to have his arm chopped off is plausibly individualistically justified. It is attractive to regard the integrity of Fred's body as a feature of Fred that is of sufficient intrinsic importance on its own - independently of whether this serves people other than Fred - to constitute a powerful reason in favour of rights protecting it, including a right that Fred's arm not be chopped off.

The self-ownership-based, labour-mixing aspects of Locke's thought offer an individualistic theory of property rights. Locke's self-ownership theory takes the intrinsic moral importance of the individual person, as secured by his or her self-ownership rights, to constitute a powerful reason for that person's holding powers of acquisition-through-labour. ${ }^{4}$ This individualistic reading of Locke might seem inconsistent with both (a) Locke's initial premiss that 'God gave the World to Men in common... for their benefit, and the greatest Conveniencies of Life they were capable to draw from it', and (b) Locke's adherence to his famous 'proviso' on acquisitions. ${ }^{5}$ (a) Some interpreters read Locke as a consequentialist or a communitarian; ${ }^{6}$ but I contend that Locke holds that God's purpose in giving the world to people in common was for the benefit of each individual person, rather than for the benefit of people collectively. ${ }^{7}$ On this reading, the reasons in favour of a specific person's acquiring private property rights in some portion of what was originally given to mankind in common will be ultimately grounded in the intrinsic moral importance of that individual person. (b) The 'Lockean proviso' specifies that any initial acquisition of property is only justified when 'enough, and as good [is] left in common for others'. ${ }^{8}$ This proviso, with its reference to 'others', appears nonindividualistic. However, on closer inspection Locke's position turns out to be individualistic because the self-ownership-based reasons in favour of property rights are 'powerful' reasons, in the technical sense outlined above. The defeasibility condition encapsulated in the proviso does not maintain that a person's powers of acquisition are defeated whenever this would serve the greater good or would serve some group or whenever a majority of contractors would wish this to be so.

\footnotetext{
4 John Locke, Two Treatises of Government (Cambridge, 1963), II. 26-8 (all references to Locke's Two Treatises cite Treatise number followed by Section number).

${ }^{5}$ For (a), see ibid. II. 34; see also II. 25-6. For (b), see II. 27.

${ }^{6}$ A. John Simmons, The Lockean Theory of Rights (Princeton, 1992), pp. 50-9; Matthew H. Kramer, John Locke and the Origins of Private Property: Philosophical Explorations of Individualism, Community and Equality (Cambridge, 1997), pp. 92-318.

7 For more details on this individualistic approach to Locke's conception of the 'public good', see my 'The Justification of Property Rights', unpublished doctoral thesis, University of Cambridge, 2002, pp. 34-41. See also Simmons, The Lockean Theory of Rights, p. 57.

${ }^{8}$ Locke, Two Treatises of Government, II. 27; see also II. 33.
} 
Instead, the proviso specifies that the property-right-justifying reason generated by an individual's self-ownership is defeasible only when 'enough, and as good' is not left for others. There are debates about how to interpret this defeasibility condition, but in my view Locke did not intend nor expect the proviso to result in attempted initial acquisitions being easily or frequently defeated - rather, Locke understood the 'proviso' as a defeasibility condition that reflects the 'powerfulness' of the self-ownership-based reasons in favour of property rights.

While Locke offers an individualistic theory specifically concerning property rights, other writers have been drawn to the general thesis that all rights are individualistically justified. For example, Hart suggests that the recognition of any right implies the recognition of the equal right of all men to be free'. ${ }^{9}$ One natural interpretation of this is that a person's rights are justified ultimately on the basis of the intrinsic importance of that individual person's freedom (an importance of equal magnitude to the intrinsic importance of the freedom of each other person). On this understanding, according to Hart a genuine feature of each right-holding person (their freedom) is of sufficient intrinsic importance on its own to ground a justification for that person's rights. Similarly, when offering a general analysis of rights, Raz writes that $X$ has a right if and only if ' $X$ can have rights and, other things being equal, an aspect of X's well-being (his interest) is a sufficient reason for holding some other person(s) to be under a duty'. ${ }^{10}$ On this view, each right is justified ultimately by a genuine feature of the right-holding person - though, unlike Hart, Raz holds that the right-justifying feature is the right-holder's interest rather than his or her freedom.

However, Raz is careful to note that his theory allows that in some cases rights will be justified only by the instrumental value of the interests of their holders in serving the interests of other people. For example, the pregnant woman's right not to be executed is justified by the instrumental value of her life for her unborn child; and the right to freedom of expression is - according to Raz - justified by the fact that everyone's having freedom of expression is of instrumental importance in securing the common good. These rights do not qualify as individualistically justified. ${ }^{11}$ Nonetheless, implicit in Raz is the assumption that the individualistic cases are the core cases. For most rights (including most property rights), it seems fair to read Raz as

${ }^{9}$ H. L. A. Hart, 'Are There Any Natural Rights?', The Philosophical Review 64 (1955), pp. $190-1$.

10 Raz, The Morality of Freedom, p. 166. See also Jeremy Waldron, The Right to Private Property (Oxford, 1988), pp. 65-102.

${ }^{11}$ For the examples, see Raz, 'Rights and Individual Well-Being', p. 50 and p. 54. See also Raz, The Morality of Freedom, pp. 178-80. 
maintaining that certain of their holders' interests are of sufficient intrinsic importance on their own to qualify as powerful right-justifying reasons.

There is a lesson to be drawn from Raz's attraction to and subsequent rejection of a fully individualistic approach to all rights. The rights that most naturally fit the individualistic picture are the stringent, morally fundamental rights that we call 'human rights' - such as Fred's right not to have his arm chopped off. It has often been noted that non-individualistic theories give inadequate accounts of human rights. For example, according to consequentialism, if the long-run collective interest would be best promoted by denying human rights to certain people, then there would be no justification for the existence of human rights for the relevant people. Concern about this counterintuitive implication is, in part, what motivates John Rawls's famous claim that ' $[u]$ tilitarianism does not take seriously the distinction between persons'. ${ }^{12}$ If human rights are individualistically justified then they will offer the special protection grounded in respect for each separate person that Rawls identifies as necessary. This, I suggest, is why Hart and Raz are attracted to individualism. However, it is implausible to regard all rights as individualistically justified. For example, consider the rights generated by parking regulations. I shall conclude this article by outlining a two-tier picture on which some rights (including most property rights) are non-individualistically justified, while other rights (the human rights) are individualistically justified, and the individualistically justified rights hold moral priority over non-individualistically justified rights. ${ }^{13}$ If this is correct, then much turns on whether property rights are individualistically justified: in arguing that most property rights cannot be individualistically justified, not only will I thereby disagree with Locke, Hart and Raz, but I will also show that most property rights cannot be human rights. ${ }^{14}$

\footnotetext{
12 John Rawls, A Theory of Justice (Oxford, 1971), p. 27.

13 Many theorists who focus specifically on human rights assume that they are individualistically justified. For example, see James Griffin's personhood-based view in his 'First Steps in an Account of Human Rights', European Journal of Philosophy 9 (2001), pp. 311-15; and see Thomas Pogge's individualistic remarks on the foundations of human rights in his World Poverty and Human Rights (Cambridge, 2002), pp. 55-8.

14 Other theorists who defend alternative individualistic approaches to property rights include Loren Lomasky, Persons, Rights, and the Moral Community (Oxford, 1987) and John T. Sanders, 'Projects and Property', Robert Nozick, ed. D. Schmidtz (Cambridge, 2002), pp. 34-58. Theorists who highlight the individualistic aspects of Locke's work include C. B. Macpherson, The Political Theory of Possessive Individualism: Hobbes to Locke (Oxford, 1962), pp. 197-221; Robert Nozick, Anarchy, State and Utopia (New York, 1974), pp. 174-82; Alan Carter, The Philosophical Foundations of Property Rights (Hemel Hempstead, 1989), pp. 13-24; J. E. Penner, The Idea of Property in Law (Oxford, 1997), pp. 187-201; Leif Wenar, 'Original Acquisition of Private Property', Mind 107 (1998), pp. 807-9; Sanders, 'Projects and Property'.
} 


\section{PREMISS (A)}

I shall use the phrase 'individualistic right-justifying feature' to refer to any genuine feature of an individual that is of sufficient intrinsic importance on its own to constitute a powerful pro tanto reason in favour of rights for that individual. The integrity of Fred's body plausibly comprises an individualistic right-justifying feature of Fred. Using this terminology, the first premiss of my argument against individualistic justifications for most property rights is as follows:

Premiss (A): any individualistic right-justifying feature that justifies noninterference rights for a given person will also be at least a weak, overrideable reason in favour of assistance rights for that person.

To defend premiss (A), we should begin by noting that any putative individualistic right-justifying feature of a person (such as the individual's needs, his or her happiness, the integrity of his or her body, his or her core interests, his or her liberty, his or her autonomously formed projects) could be protected and promoted by the existence of both non-interference rights and assistance rights held by that individual. Consider Ingrid's need to continue living. Both noninterference rights (e.g. rights not to be shot or stabbed) and assistance rights (e.g. rights to medical assistance, rights to be supplied with the foods necessary for survival) could contribute significantly to the satisfaction of Ingrid's need to continue living. Similarly, consider Jill's pursuit of her autonomously chosen project - to make a table from the lump of wood she has found. ${ }^{15}$ Both non-interference rights (e.g. rights allowing Jill freedom to use the lump of wood as she wishes) and assistance rights (e.g. rights to training in woodwork, and to the provision of carpentry tools) could contribute significantly to Jill's ability to pursue her project. There might seem to be three impediments to the inference from (i) the fact that individualistic right-justifying features would be protected and promoted if a person held assistance rights as well as non-interference rights, to (ii) the conclusion that premiss (A) is correct. However, I argue below that these apparent impediments fail to undermine this inference.

\section{A. Levels of moral importance and levels of protection}

An opponent of my inference from (i) to (ii) could plausibly argue that certain individualistic right-justifying features (such as Jill's carpentry project) are only of moderate moral importance - importance sufficient to justify a few non-interference rights, but not to comprise a reason in

\footnotetext{
${ }^{15}$ For two prominent individualistic arguments for property rights based on the moral importance of the individual's projects, see Lomasky, Persons, Rights, and the Moral Community and Sanders, 'Projects and Property'.
} 
favour of all the rights for that person that would maximally protect or promote that feature.

It should be conceded that sometimes merely moderately important features of an individual are of sufficient - although only moderate intrinsic importance on their own to justify rights. And such moderately important individualistic right-justifying features will not constitute reasons in favour of all the rights necessary to secure maximum protection for the right-justifying features. For example, if Jill's carpentry project is of moderate individualistic right-justifying importance, then at most it will constitute a reason in favour of the rights that would make it moderately likely that Jill will be able to proceed with her carpentry project, rather than all the rights that would maximize Jill's success at this project.

But this line of reasoning does not undermine the inference from (i) to (ii). To make it moderately likely that Jill's carpentry project flourish, some fairly undemanding assistance rights (e.g. rights demanding that we provide Jill with a hammer if her project requires one and we have one available) would be just as useful as some fairly undemanding non-interference rights (e.g. rights demanding that we let Jill proceed with her carpentry unless we need the wood urgently for other activities). The distinction between non-interference rights and assistance rights does not map onto any distinction between greater and lesser moral importance ascribable to a given individualistic right-justifying feature - instead, even right-justifying features of lesser moral importance will be as usefully served by assistance rights as by non-interference rights. So the fact that individualistic right-justifying features are sometimes of moderate rather than great moral importance does not undermine my inference from (i) to (ii).

\section{B. The burdens and conflicts of assistance}

The duties correlative to rights of assistance are generally more burdensome than the duties correlative to non-interference rights; also, rights of assistance tend to generate many conflicts, while noninterference rights generate fewer conflicts. ${ }^{16}$ These facts suggest

16 There can be some extremely burdensome non-interference rights (e.g. it is burdensome for a parent to respect a divorced partner's custodial rights over their child, even though these are primarily non-interference rights). And assistance rights need not always generate conflicts; in some situations (e.g. with abundant resources), it might turn out that everyone can be given the assistance they need. Nonetheless, assistance rights tend to involve more burdensome duties than non-interference rights, because assisting tends to involve more time and effort than merely refraining from interfering with someone (Lomasky, Persons, Rights, and the Moral Community, pp. 94100); and assistance rights tend to generate more conflicts than non-interference rights for example, if both you and Philip hold rights to the assistance of a heart pacemaker, then your rights will conflict if society's resources can only afford to buy one pacemaker. 
that any reasons in favour of assistance rights are likely frequently to be overridden by countervailing concerns about the burdens and conflicts that would be created by assistance rights. On this basis, an opponent of my inference from (i) to (ii) might argue that even when individualistic right-justifying features could be protected or promoted by certain assistance rights, such right-justifying features will not normally justify these assistance rights; instead, putative justifications for assistance rights will normally be overridden by considerations about the burdens and conflicts that the assistance rights would generate.

This is not a genuine difficulty for premiss (A). This premiss maintains merely that any right-justifying feature that justifies noninterference rights for an individual will also constitute at least weak, overrideable reason in favour of assistance rights for that individual. Premiss (A) is thereby compatible with the contention that most reasons in favour of assistance rights will normally be overridden by considerations about the burdens and conflicts that the assistance rights would generate.

\section{A 'basic moral difference' between assistance and non-interference}

Some theorists hold that all assistance rights are, as a matter of basic moral fact, in some way intrinsically less important than noninterference rights. I shall call this 'the basic moral difference thesis' ${ }^{17}$ There are various versions of the basic moral difference thesis, and only one would undermine my inference from (i) to (ii). This is the extreme version which holds that there can never be any reason - even a weak overrideable reason - in favour of assistance rights. If this extreme version is correct, then of course the fact that Ingrid's need to continue living would be usefully protected by Ingrid's holding assistance rights cannot be a reason in favour of such assistance rights because, as a matter of 'basic moral fact', there can never be such pro-assistancerights reasons.

Staunch libertarians might dig their heels in here and endorse the extreme version of the basic moral difference thesis. But there is little to recommend this extreme version. First, intuitively it seems to me that there must sometimes be at least weak, overrideable reasons in favour of assistance rights. If my holding a certain assistance right (e.g. to subsistence provisions) would offer the best way to protect some very important aspect of me (e.g. this right would save my life), and this right would not place enormous burdens on others, then it is plausible to

\footnotetext{
17 For discussion, see for example Simmons, The Lockean Theory of Rights, pp. 345-6; Warren Quinn, 'Actions, Intentions and Consequences: The Doctrine of Doing and Allowing', in his Morality and Action (Cambridge, 1993), pp. 149-74.
} 
maintain that there must be some reasons - though perhaps weak and overridden - favouring my holding such an assistance right. Second, this intuition can be supported. Individualistic justifications of rights are teleological in the following sense: they maintain that certain intrinsically important features of an individual (perhaps certain interests, freedoms, projects) constitute the ends or tele of justifications of rights held by that individual. These features of the individual stand out as demanding a response appropriate to their value, and the individual's rights are justified as means of respecting, serving or promoting these valuable features. It follows that when respect for these individualistic right-justifying features could be as well secured by assistance rights as non-interference rights, the individualistic approach must generate at least weak pro tanto reasons in favour of assistance rights. A critic of my inference from (i) to (ii) might deny that all genuinely individualistic theories must be teleological, but I do not see how such a denial could work. Popular non-teleological theories of rights - such as Kantian constructivism or contractarianism - are non-individualistic, and it is very unclear how a right could be justified as the appropriate response to the great intrinsic value of some feature of its holder, without that justification being teleological in the sense outlined here. ${ }^{18}$

Less extreme versions of the basic moral difference thesis do not deny that there can ever be reasons in favour of assistance rights; they merely regard such reasons as always intrinsically less important than the reasons supporting non-interference rights. But so long as it is possible for there to be reasons favouring assistance rights, then premiss (A) is not undermined. Premiss (A) claims merely that whenever there exists a genuine individualistic right-justifying feature of a person $\mathrm{P}$, then that feature would constitute at least weak, overrideable reason in favour of assistance rights for $\mathrm{P}$. This premiss is compatible with the thesis that reasons in favour of non-interference

\footnotetext{
18 Are self-ownership-based individualistic justifications teleological? In my view, if they are not then they are not genuinely individualistic. A genuinely individualistic selfownership based theory will regard the importance of some aspect of the individual (perhaps the basic importance of the individual as such, or the importance of the individual's sovereignty over himself or herself or, as Locke (Two Treatises of Government, I. 92) puts it, 'the Subsistence and Comfort' of the individual) as the telos of justifications of rights for that individual; on this approach, the individual's rights - including his or her fundamental self-ownership rights - are justified as appropriately serving, respecting or promoting this telos. By contrast, a self-ownership-based theory that offered no teleological grounding for rights but instead took the existence of certain self-ownership rights for everyone as 'basic' and ungrounded could not be individualistic: it would not regard the individual's rights as grounded in the intrinsic importance of some aspect of the right-holder.
} 
rights will always, as a matter of 'basic moral fact', be more important than reasons in favour of assistance rights.

I have completed my defence of premiss (A). Any individualistic rightjustifying feature of a person P would be usefully supported by P's holding both non-interference rights and assistance rights. And we have seen no reason to reject the conclusion that any individualistic right-justifying feature that justifies non-interference rights for $\mathrm{P}$ will therefore also constitute at least a weak, overrideable reason in favour of assistance rights for $\mathrm{P}^{19}$

\section{PREMISS (B)}

The second premiss of my argument is:

Premiss (B): property rights primarily comprise rights to non-interference.

My property rights in my pen comprise privileges to use my pen in various ways, and claims protecting these privileges from being impeded by various sorts of actions of others, plus powers to alienate these claims and privileges (e.g. through selling my pen). ${ }^{20} \mathrm{I}$ am not protected, by my property-right-based claims, against every possible impediment to my using my pen as I wish. For example, if I become too old and weak to use my pen, my property rights do not include a claim that I be assisted in using it. Rather, the claims conferred by my property rights in my pen are primarily claims to non-interference. Similarly, property rights in houses, telephones, money, ideas all primarily comprise privileges protected by non-interference claims. There are perhaps some claims to assistance included within the cluster of rights which constitute one's property rights in something. For example, I think that property rights include claims that one's goods be returned to one when they have been stolen (or else that one be compensated). And property rights include claims that one's executors carry out one's bequests. ${ }^{21}$ But property rights involve no

19 One alternative line of criticism might maintain that there are certain individualistic right-justifying features - such as autonomy - that could never be served or respected by assistance rights. But I do not believe there are any such features. For example, respect for a person's autonomy can require assisting that person (e.g. by educating or informing them), instead of mere non-interference. See Raz, The Morality of Freedom, pp. 407-12.

${ }^{20}$ My terminology here draws on Wesley N. Hohfeld, Fundamental Legal Conceptions (New Haven, 1964), pp. 35-64. In my view, a right can be constituted by a single claim, privilege, power, immunity or liability, or by some cluster of several claims or several privileges or several powers or several immunities or several liabilities, or by some mixed cluster (e.g. involving claims plus privileges or immunities plus powers plus privileges etc.). See my 'Rights: Beyond Interest Theory and Will Theory?', Law and Philosophy 23 (2004), and my 'Why Aren't Duties Rights?', The Philosophical Quarterly 56 (2006).

21 Alan Ryan, Property (Milton Keynes, 1987), p. 62 and pp. 83-4. Some have questioned whether property rights genuinely include any rights to assistance. Although 
claims to assistance beyond a few of this sort. This is a conceptual truth: property rights are primarily claims to non-interference. ${ }^{22}$

\section{FROM PREMISSES (A) AND (B) TO (C)}

My discussion of premisses (A) and (B) should be understood as implying the following:

Intermediate conclusion $(C)$ : any individualistic justification of property rights for a particular person will also generate at least weak overrideable reasons in favour of more assistance rights for that person than simply those few assistance rights (such as rights to have his or her property returned to him or her after theft, and rights to assistance with bequest) that are included within the person's property rights.

For example, consider an individualistic justification for property rights based on the moral importance of the individual's continued living. If Philip's property rights in his food are justified by the individualistic right-justifying importance of Philip's continued living, then Philip's continued living will also constitute at least a weak overrideable reason in favour of assistance rights additional and parallel to Philip's property rights in his food (such as rights requiring that Philip be given medical care if needed for his continued living, and that he be provided with food if he cannot afford to buy any). My discussion of premisses (A) and (B) suggests that there could be no individualistic justification for Philip's property rights in his food that would not also constitute at least a weak, overrideable reason for some such parallel, additional assistance rights.

\section{PREMISS (D)}

For some property rights, the features of the property owner that could individualistically justify those property rights would also constitute reasons-in-favour-of-additional-assistance-rights that it is plausible to

I think such a view mistaken, it is notable that this view would sharpen rather than weaken my argument: if property rights include no rights to assistance then, given premiss (A), any individualistic justification for a particular person's property rights must obviously also generate reasons in favour of assistance rights additional to those property rights, as my intermediate conclusion (C) asserts.

${ }_{22}$ Most of the rights which A. M. Honoré regards as comprising ownership are non-interference rights. For example, Honoré's 'right to possess', 'right to use', 'right to manage' and 'right to the capital' are all constituted primarily by claims to noninterference (A. M. Honoré, 'Ownership', Oxford Essays in Jurisprudence: A Collaborative Work, ed. A. G. Guest (Oxford, 1961), pp. 107-47). Similarly, Frank Snare's analysis of property rights highlights their character as non-interference rights, as does J. E. Penner's analysis, which stresses the 'right of exclusive use' (which he elaborates as a right of non-interference) (Frank Snare, 'The Concept of Property', American Philosophical Quarterly 9 (1972), pp. 200-6; Penner, The Idea of Property in Law, pp. 68-104 and 128-52). 
see as genuine reasons. For instance, suppose that Philip owns very little other than his food; suppose that without his property rights in his food Philip will starve. In this situation, Philip's property rights in his food could be genuinely individualistically justified by the importance of Philip's continued living. For, crucially, the rightjustifying importance of Philip's continued living also constitutes at least a weak overrideable reason in favour of additional assistance rights (such as a right to be provided with food if Philip cannot afford to buy any, and a right to medical assistance when Philip's life is threatened) for which it is plausible to see there as genuinely being at least weak, overrideable reason. Similarly, if Philip's property rights in his food were essential to secure Philip an essential degree of autonomy, then again in this situation Philip's property rights in his food could be genuinely individualistically justified. For the right-justifying importance of Philip's attaining an essential degree of autonomy constitutes at least a weak, overrideable reason in favour of additional assistance rights (such as a right to a minimal education) for which it is plausible to see there as genuinely being at least weak, overrideable reason.

But most property rights do not fit this picture. My premiss (D) asserts:

Premiss (D): for most of the property rights that are recognized by current legal systems in wealthy nations, any features of the property owner that might appear capable of grounding individualistic justifications for those property rights would also constitute at least weak, overrideable reasons in favour of additional parallel assistance rights for which it would be implausible to see there as being genuine reason.

This is because most of the property rights in wealthy nations protect much more than the property-holder's vital interests or essential freedoms. It is plausible that there are reasons in favour of assistance rights protecting people's vital interests and essential freedoms (such as Philip's continued living or his minimal autonomy), but it is not plausible that there are even weak overrideable reasons in favour of assistance rights protecting the features of a wealthy person that their property rights in inessential goods protect.

For example, consider Maureen's property rights in her expensive new car. Let us assume that Maureen is fairly wealthy, with many assets in addition to her car. In this situation, what feature of Maureen might ground an individualistic justification for her property rights in her expensive new car? Note that these property rights cannot be individualistically justified by Maureen's vital interest in simply continuing to live or by Maureen's simply attaining an essential degree of autonomy because, given Maureen's wealthy circumstances, 
her property rights in her expensive new car secure so much more than a bare essential degree of autonomy for her, and do so much more than ensure her continued living, that such property rights cannot be justified merely as a necessary response to her essential autonomy or interest in continued living. Instead, might Maureen's property rights in her expensive new car be justified on the basis that Maureen's interest-in-using-her-talents-to-secure-herself-a-fairlyhigh-level-of-resources is of individualistic right-justifying importance? If this interest were sufficient on its own to ground a justification for Maureen's property rights in her car, then (C) tells us that this interest would also constitute at least a weak overrideable reason in favour of additional assistance rights protecting this interest. For example, this interest of Maureen's in using her talents to secure a fairly high level of resources would constitute at least a weak, overrideable reason in favour of rights to the free assistance of a 'shopping consultant', who would help Maureen select an appropriate car. But it is, I think, extremely implausible to hold that there could be any reason - even a weak, overrideable reason - in favour of such assistance rights for wealthy Maureen. And thus it is implausible to hold that Maureen's property rights in her expensive new car are justified by her interest in using her talents to secure herself a fairly high level of resources.

The difficulty for the individualistic approach is that, given Maureen's wealthy circumstances, any feature of Maureen to which one might appeal in attempting to offer an individualistic justification for her property rights in her expensive new car would turn out also to qualify as a reason in favour of assistance rights for which it would be implausible to see there as being any genuine reason (even weak, overrideable reason). The importance of Maureen's attaining the high level of autonomy that her expensive car provides, or her interest in making herself look smart, are features of Maureen that, if of individualistic right-justifying importance, would justify her holding property rights in her expensive new car. But they would each also constitute at least weak, overrideable reasons in favour of additional assistance rights for Maureen (e.g. rights to be assisted in attaining the high level of autonomy involved in driving at high speeds in a valuable status symbol, or rights to free provision of a beauty makeover) for which it is implausible that there are even weak overrideable reasons. ${ }^{23}$ It seems to me to be a brute moral fact

${ }^{23}$ One might think that Maureen's property rights in her expensive new car are justified by her interest in using her high monetary income as she wishes. But this will only qualify as an individualistic justification if Maureen's property rights in her high income are themselves individualistically justified. Perhaps her property rights in her high income appear individualistically justified by her self-ownership. But it is doubtful 
that - barring unusual circumstances (e.g. where a shopping consultant is necessary to compensate for a severe disability) - there can be no reasons whatsoever (not even weak and overridden) in favour of additional assistance rights parallel to wealthy people's property rights in inessential goods. The free assistance of shopping consultants or free provision of status symbols is, in my view, just not something to which a person who is already wealthy can ever normally have a right, nor can there even be weak overrideable reasons in favour of such a right.

Similar difficulties beset my earlier example of Jill's carpentry project. If Jill's property rights in the wood were genuinely justified by the moral importance of Jill's pursuit of her chosen table-making plan, then (C) tells us that there must also be at least weak overrideable reason in favour of Jill's holding additional assistance rights, parallel to her property rights in the wood. For example, there would be reason in favour of Jill's holding rights to carpentry lessons if she lacks skills in woodwork. But if Jill is already fairly wealthy, then it is not plausible to see there as being such reasons (even if weak and overrideable). Rather, I suspect that - unless the wood is essential for Jill's survival, or for the securing of an essential degree of autonomy for Jill - any feature of Jill that might appear to justify her property rights in the lump of wood would turn out also to qualify as a reason in favour of assistance rights for which it is not plausible that there is genuine reason. It follows that Jill's property rights in her lump of wood cannot be individualistically justified.

Note that my argument applies to contextually specific property rights, property rights held by specific people in specific situations, rather than to general types of property rights (such as 'all property rights in expensive cars' or 'all property rights in lumps of wood'). If the lump of wood offered Jill's only means of survival, or if the wood offered the only means of securing an essential degree of autonomy for Jill, then her property rights in the wood might be individualistically justifiable. For in these circumstances, Jill's property rights in the lump of wood would be individualistically justifiable on the basis of individualistic right-justifying features (Jill's survival or Jill's attaining an essential degree of autonomy) that would constitute at least weak, overrideable reasons in favour of assistance rights for which it is plausible that there

that the individualistic right-justifying feature that justifies Maureen's self-ownership rights (perhaps the importance of her control over herself - see n. 18 above) would justify rights to a very high income - for if it were to do so then it would also qualify as at least a weak, overrideable reason in favour of implausibly extensive assistance rights, assistance rights to the provision of the very great control that a high income secures (such as rights to the existence of an economic system that places a high monetary value on Maureen's talents). 
are genuinely at least weak, overrideable reasons (such as rights to the resources necessary for survival, or to the resources necessary for an essential degree of autonomy). Similarly, if Maureen's circumstances were less wealthy, her property rights in her expensive new car might be individualistically justifiable. Suppose that Maureen loses all her assets except her expensive new car (perhaps her house burns down and her bank is robbed while she is out driving). Under these circumstances, her property rights in her car might turn out to offer her only means of attaining an essential minimum level of freedom and perhaps even, through selling the car, her only means of continued livelihood. In this situation, Maureen's property rights in her expensive car are plausibly individualistically justifiable, because in this situation her property rights in the car are justifiable on the basis of features of Maureen (such as her attaining an essential minimum level of freedom, or her continued living) that constitute reasons in favour of additional assistance rights (such as rights to medical care enabling Maureen to continue to live) that it is plausible to see as genuine reasons.

\section{CONCLUSION OF THE ARGUMENT}

The argument does not establish that no property rights can be individualistically justified. Rather, it establishes that if certain contextually specific property rights are individualistically justified, then there must also be at least weak, overrideable reasons in favour of the additional parallel assistance rights that would protect those morally important features of the property holder that justify the property rights in question. Some property rights in particular contexts (e.g. those which protect the individual's continued living, like Philip's property rights in his food) are plausibly accompanied by reasons supporting such additional parallel assistance rights. Others are not (e.g. Maureen's property rights in her expensive new car, when held in a context in which Maureen owns many other assets as well). These latter property rights cannot be individualistically justified.

\section{AN OBJECTION: STATE ENFORCEMENT OF PROPERTY RIGHTS}

Many states expend considerable resources to defend and enforce the property rights of their members. The police service, the judicial system, environmental protection agencies and CCTV surveillance systems all play a major role in defending and enforcing property rights. The property-protecting activities of these bodies should perhaps be construed as assistance for property-owners. This construal of the 
state enforcement of property rights might be used to develop a criticism of my argument. The criticism accepts that individualistic justifications for property rights would generate reasons in favour of a range of assistance rights. The criticism questions (D)'s assertion that the assistance rights that would be supported by individualistic justifications are, in the case of most property rights, assistance rights for which it is implausible to see there being genuine reasons. Instead, the criticism contends that all property rights are matched by certain assistance rights that it is plausible to ascribe to property-owners: rights to the assistance of the state in the protection of property (through the work of the police, the judiciary, etc.).

This criticism should be rejected because individualistic justifications for property rights would support significantly more extensive assistance rights than mere rights to the assistance of the state in the protection of property. My examples have already made this clear: the assistance rights supported by putative individualistic right-justifying features (such as Philip's continued living, or Jill's carpentry project) go beyond mere property-protection rights -instead, they include such rights as a right to medical assistance, or a right to carpentry lessons.

In response, a defender of the criticism might modify their point by arguing that while individualistic justifications appear to generate reasons in favour of extensive assistance rights, the excessive demands that would be placed upon a society's resources by such extensive assistance rights override the reasons for such assistance rights. Instead, the defender of the criticism might argue that in protecting the owner's property rights through the police and the judiciary, the state has done enough by way of positive assistance for those features of right-holders which justify their property rights. The difficulty for this line of criticism is that if one accepts that the excessive 'demandingness' of such rights as Maureen's right to a free shopping consultant overrides the reasons in favour of such rights (leaving justification only for the less extensive assistance rights which are met by the state enforcement of property rights), then one offers an implausible explanation for why excessively demanding assistance rights are not justified. Rather than maintain that Maureen would have held extensive assistance rights, including a right to a shopping consultant, were such rights not excessively demanding, it is more plausible to maintain that there is no reason, not even an overridden one, for Maureen's right to a shopping consultant. To adopt this stance, one must abandon the individualistic approach to the justification of Maureen's property rights in her expensive new car. Only on this basis will one eschew the implausible view that there are overrideable reasons in favour of extensive assistance rights for Maureen. 


\section{IMPLICATIONS OF THE ARGUMENT}

My argument implies that the only property rights that can be justified individualistically are those-like Philip's property rights in his foodthat are individualistically justifiable on the basis of features of the property-owner that also support additional assistance rights for which it is plausible that there could be at least weak, overrideable reason. This delineates a limit to the success of any individualistic approach to property rights. For most of the specific property rights recognized by existent legal systems in wealthy nations - such as Maureen's property rights in her expensive new car, or Margaret's property rights in seven hundred acres of farmland - there are not plausibly even weak, overrideable reasons in support of additional parallel assistance rights protecting the features of the property-owner that prima facie one might think could individualistically justify these property rights. Thus most of the specific property rights recognized by existent legal systems in wealthy nations cannot be individualistically justified. If they are justified at all, then their justification must, despite the claims of such writers as Locke, Hart and Raz, be non-individualistic. ${ }^{24}$

I promised to conclude by outlining a two-tier view of rights. This two-tier picture regards individualistic justification as the hallmark of human rights, rights that take moral priority over other rights whose justification is non-individualistic. I am attracted to the following twotier view, according to which interests are central to the justification of all rights, and non-individualistically justified rights are justified on consequentialist grounds:

- Human rights are justified individualistically, on the basis of the importance of certain interests of the individual right-holder. I suggest that the human rights will normally ${ }^{25}$ include rights securing

\footnotetext{
${ }^{24}$ It is worth noting why non-individualistic justifications need not generate reasons in favour of extensive assistance rights, in the way that individualistic justifications must: non-individualistic goals would often be hampered rather than promoted by endowing individual people with assistance rights. For example, even in a 'morally ideal world' in which everyone did their best to respect all rights, the stability of a group would often be best promoted by endowing each member of the group only with non-interference rights and not assistance rights. By contrast, in a world in which everyone was going to try to respect all rights, any given individualistic right-justifying feature would always be best promoted if the relevant individual held assistance rights as well as non-interference rights (and thus, e.g., the individualistic right-supporting importance of the stability of the environment for a given individual will always generate reasons in favour of assistance rights for that individual - such as rights-to-be-provided-with-the-resources-necessaryto-maintain-his-or-her-stable-environment - as well as non-interference rights).

${ }_{25}$ For an argument that any individualistic approach of this type will imply that human rights are in a certain sense non-universal, see my 'Human Rights, Individualism and Cultural Diversity', Critical Review of International Social and Political Philosophy 8 (2005).
} 
their holder's continued living and bodily integrity, and rights securing a minimal level of autonomy for their holder.

- Other rights (including promissory rights and various legally created rights such as my right to park in a residents' parking bay) are justified on the basis of the importance of the collective interest.

- The human rights are more important: they shape what other rights can be justified.

My two-tier picture reflects the twin facts that (a) sometimes rights are necessary to protect important interests of individual people, interests whose individual importance is incompatible with their being interpersonally aggregated and then maximized (e.g. consider Fred's interest in his bodily integrity), but also (b) in other cases rights are simply of instrumental use in securing collective benefits (e.g. given the co-ordination problems generated by collective life, rights-creating regulations can be useful for promoting aggregate welfare - consider Mary's right to park in a residents' parking bay). By regarding the individualistically justified rights as more important, I hold that it is more important to respect those aspects of an individual's rightsprotected realm whose justification is grounded ultimately in the intrinsic importance of interests of the right-holder, than to respect those aspects of this realm that are justified by what they do for the wider community. According to this two-tier picture, my argument against individualistic justifications for most property rights implies that most property rights occupy the lower, less important tier of rights. Perhaps some particular property rights qualify as morally important human rights, such as Philip's property rights in his food. But most property rights do not.

The two-tier picture in the paragraph above requires more development. ${ }^{26}$ But this should not obscure the important implications of the conclusions we have already reached. If most property rights cannot be individualistically justified, then whether or not my two-tier theory is correct, we must endorse the following disjunctive conclusion: either most property rights are unjustified or most property rights are non-individualistically justified. One cannot accept that most property rights are justified, without accepting that most of Ingrid's property rights will be justified ultimately on the basis of what these rights do not merely for Ingrid, but for other people as well. This is a conclusion of significant political import. It entails that most of Ingrid's property

\footnotetext{
${ }^{26}$ See my 'The Justification of Property Rights', esp. pp. 99-102, my 'Human Rights, Individualism and Cultural Diversity', and my 'Human Rights and Positive Duties', Ethics and International Affairs 19 (2005), esp. pp. 36-7.
} 
rights are unjustified if they do not serve 'the collective interest', 'the community' or 'shared' or 'mutual' concerns.

This conclusion might seem to offer an immediate refutation of right-wing libertarianism, and a justification for such practices as compulsory purchase and taxation. But it would be hasty to draw these inferences. There might be consequentialist or communitarian or some other non-individualistic reason to eschew taxation and compulsory purchase, and to endorse the politics of right-wing libertarianism. ${ }^{27}$ For example, empirical research into the productivity of laissezfaire' capitalism might show that a regime of strong property rights and low taxation better promotes the collective interest than would alternative regimes. What my argument establishes is not that right-wing libertarian property systems must be rejected and such practices as compulsory purchase and taxation must be endorsed, but that one's approach to these issues will turn ultimately on nonindividualistic questions (e.g. questions concerning whether right-wing libertarian property systems or systems involving heavier taxation better serve 'the community' or 'the collective interest'). This follows from my conclusion that most of an owner's property rights are not fundamentally there to serve that property-owner, but are rather justified by how they serve the wider community of which that owner is a part. $^{28}$

Rowan.Cruft@stir.ac.uk

${ }^{27}$ For arguments of broadly this type, see Richard A. Epstein, 'On the Optimal Mix of Private and Common Property' and David Schmidtz, 'The Institution of Property', both in Property Rights, ed. E. F. Paul, F. D. Miller, Jr., and J. Paul (Cambridge, 1994).

${ }_{28}$ Early versions of this article were presented at King's College, Cambridge, and at a meeting of the Scots Philosophical Club in Stirling. I am grateful for comments received at these events, and owe special thanks to Jimmy Altham, Michael Brady, Roger Crisp, Antony Duff, Antony Hatzistavrou, Matthew Kramer, Hallvard Lillehammer, Sandra Marshall, Nigel Simmonds and Jonathan Wolff. 